\title{
Irradiation Effect on Oxidative Condition and Tocopherol Content of Vegetable Oils
}

\author{
Stavros Lalas ${ }^{1, *}$, Olga Gortzi ${ }^{1}$, John Tsaknis ${ }^{2}$ and Konstantinos Sflomos ${ }^{2}$
}

1 Department of Food Technology, Technological Educational Institution (T.E.I.) of Larissa, Karditsa, GR-43100, Greece; E-mail: slalas@ teilar.gr. E-mail: ogortzi@teilar.gr

2 Department of Food Technology, Technological Educational Institution (T.E.I.) of Athens, Egaleo, Athens, GR-12210, Greece; E-mail: jtsaknis@teiath.gr. E-mail: ksflomos@teiath.gr

* Author to whom correspondence should be addressed: E-mail: slalas@teilar.gr

Received: 30 April 2007 / Accepted: 22 May 2007 / Published: 15 June 2007

\begin{abstract}
The effect on induction period and tocopherol content after $\gamma$-irradiation on samples of olive oil and seed oils (sunflower and soybean) was determined. In seed oil samples $0,100,200$ and $300 \mathrm{ppm}$ of $\delta$-tocopherol were added before irradiation with 1, 2 and $3 \mathrm{kGy}$. The results of induction period showed that, after irradiation, all samples presented a significant decreased in resistance to oxidation. However, this decrease was minimized when $\delta$-tocopherol was added. Irradiation significantly decreased the level of tocopherols. $\delta$-Tocopherol appeared more sensitive in irradiation process than $\alpha$ - and $\gamma$-tocopherol. The addition of $\delta$-tocopherol significantly reduced, in most cases, the depletion of the other tocopherols.
\end{abstract}

Keywords: $\gamma$-irradiation, lipids, oxidation, tocopherol.

\section{Introduction}

Ionizing radiations are used for the treatment of various food products. However, only electromagnetic waves (visible light, x-rays, $\gamma$-rays, ultraviolet light, infrared light, etc) and electrons can be used in food process, while neutrons, deuterons and $\alpha$-rays cause extensive damage to food [1]. The irradiation extends the storage life of food and improves the safety via the reduction of pathogenic and spoilage micro-organisms [2]. The ionizing radiation has the ability to start a high number of 
chemical changes in gas, liquid and solid phase of food. With the exposure in irradiation initially ionization of water takes place followed by the production of free radicals and peroxides [3]. Many intermediate products are formed and react each other or with other components of the system [1]. The reactions of these intermediate products with the ingredients of food are numerous. Each group of food ingredients such as carbohydrates, proteins and other nitrogen containing compounds, fats and oils, vitamins, enzymes and coloring compounds can react with certain intermediate products and form new intermediate products, many of which have high chemical activity [3-5]. The reactions of oxidation, free radical forming and reduction belong to this category.

Stevenson [6] proved that irradiation does not have repercussions in the general nutritional value of foods and the oxidative changes caused are similar to those observed with the use of conventional techniques of food treatment. Nevertheless, a combination of irradiation and other methods of treatment, such as cooking, can lead to accelerating oxidative destruction of foods [7]. The storage of irradiated lipid food, in the presence of oxygen, accelerates the autoxidation [8]. It has been proved that irradiation accelerates the oxidation of unsaturated fatty acids and cholesterol during frozen storage of foods [9-10]. In lipids, many of the reactions resemble to those of the peroxidation from molecular oxygen, but special reactions can also take place owed exclusively to ionizing radiation [1].

Vitamin $E$ is the most labile in irradiation from all fat soluble vitamins [11-13]. Irradiation decreased $\alpha$-tocopherol levels during irradiation of various kinds of meat [11-13]. The addition of tocopherols (in animal feed) leaded to the protection of phospholipids and cholesterol by breaking the chain of oxidation in meat fat [14]. Moreover, it prevented the loss of water detention, color and flavor of food during storage.

As determined by Fuster et al. [15], triacylglycerols can be used as a model system (which provides the natural complexity of fatty distribution). So, a vegetable oil can be used to determine the effect of irradiation on lipids without interference of other food ingredients (proteins, carbohydrates, etc.).

In this work, we tried to determine the effect of $\gamma$-irradiation on oxidative condition and tocopherol content of lipids using various vegetable oils as model systems. The oxidative condition before and after irradiation of seed oil samples with addition of $\delta$-tocopherol was also determined. $\delta$-Tocopherol was selected since, to our knowledge, there were no previous reports on the effect of irradiation on that tocopherol. Additionally, $\delta$-tocopherol was not expected $[16,17]$ to show antioxidant action higher than its $\alpha$-homolog during irradiation since the process was carried out at room temperature.

\section{Results and Discussion}

The results of induction period (Table 1) showed that irradiation caused a significant $(\mathrm{P}<0.05)$ decrease in resistance to oxidation of all samples. As expected, olive oil samples presented a longer period of induction. After irradiation with $3 \mathrm{KGy}$, the lowest decrease was observed in olive oil samples $(9.6 \%)$ and the highest in soybean oil (34.2\%). The oxidative stability of olive oil is related to some extent to the presence of $\alpha$-tocopherol [18]. Kiritsakis and Min [19] reported that olive oil contains up to $150 \mathrm{mg} / \mathrm{kg} \alpha$-tocopherol. However, the stability of olive oil could not be explained only on the basis of tocopherol action. It is known that the olive mesocarp contains phenolic compounds, which are present in the olive oil and considerably increase the stability against oxidation of the oil [19]. To these compounds, $\alpha$-tocopherol and of course the fatty acid composition [18] should be 
attributed the lowest decrease (Table 2) of $\alpha$-tocopherol in olive oil after irradiation (68.3\%) in contrast to the other two oils. These results agree with those of Zhu et al. [20] who reported that depletion of $\alpha$-tocopherol (during protection of low density lipoproteins against oxidation) was delayed after addition of certain flavonoids which regenerated the vitamin.

In all cases, the addition of $\delta$-tocopherol significantly $(\mathrm{P}<0.05)$ increased the induction period (at the same irradiation dose) of soybean and sunflower oil (Table 1). Particularly, the increase of induction period was up to $28.9 \%$ and $34.8 \%$ at $3 \mathrm{KGy}$ for sunflower and soybean oil, respectively. Additionally, the reduction of induction period, during the progress of the irradiation, appeared proportional to the level of addition of $\delta$-tocopherol. Specifically, the reduction of induction period after $3 \mathrm{KGy}$ dose of irradiation of soybean oil was from $34.2 \%$ (control) to $21.4 \%$ (300 ppm of $\delta$ tocopherol) and sunflower oil from $25.8 \%$ (control) to $18.0 \%$ (300 ppm of $\delta$-tocopherol). These results are in line with those reported by Bourgeois and Czornomaz [16] and Von Pongracz et al. [17] who reported that the antioxidant activity of tocopherols is $\delta>\gamma>\alpha>\beta$ in a temperature between 80 and $120{ }^{\circ} \mathrm{C}$ and $\alpha>\gamma>\beta>\delta$ in a temperature between 20 and $60{ }^{\circ} \mathrm{C}$. During the determination of the induction period (Rancimat method) where the temperature was set at $90{ }^{\circ} \mathrm{C}, \delta$-tocopherol increased the induction period by acting as antioxidant with higher activity.

As shown in Table 2, irradiation decreased the level of tocopherols. This decrease was significant $(\mathrm{P}<0.05)$ in all samples. The highest decrease in $\alpha$-tocopherol was shown in soybean oil without additional $\delta$-tocopherol (up to $92.6 \%$ ). $\delta$-Tocopherol showed even higher decrease (up to $93.1 \%$ ) and appeared more sensitive in irradiation process than $\alpha$-tocopherol, while $\gamma$-tocopherol appeared the most resistant (up to $92.3 \%$ of reduction). However, it should be stated that in samples with low tocopherol concentration the depletion was complete (Table 2). Lakritz and Thayer [11] who reported a decrease in $\alpha$ - and $\gamma$-tocopherol (30 and $15 \%$, respectively) after irradiation of fresh chicken breasts. Additionally, Lakritz and Thayer [12] reported a decrease (6\%) in $\alpha$-tocopherol but no significant changes in $\gamma$-tocopherol after irradiation. In the study of Lakritz et al. [13], $\alpha$-tocopherol decreased significantly in meat irradiated with 0-9.4 kGy at $5{ }^{\circ} \mathrm{C}$. On the contrary, Galvin et al. [7], who studied the retention of $\alpha$-tocopherol and lipid oxidation after irradiation ( 2.5 and $4.0 \mathrm{kGy})$ in cooked minced chicken (fed with a diet supplemented with $\alpha$-tocopheryl acetate), reported no affect of irradiation on the $\alpha$-tocopherol content. Concerning the lipid stability, the same authors indicated that oxidation (measured by thiobarbituric acid-reacting substances and cholesterol oxidation products) was accelerated during storage but was possible to control it when chicken diet was supplemented with of $\alpha$-tocopheryl acetate. It appears that there is a disagreement between various authors on the percentage of tocopherol depletion as a consequence of irradiation which can be attributed to the different experimental conditions and samples. The results of our work are also difficult to be compared with the aforementioned studies since it was conducted under different experimental conditions (room temperature) and on different samples (vegetable oils).

The mechanism of the antioxidant action of tocopherols is thoroughly described by many authors [21-22]. Extensive studies have also been reported on the synergistic behavior of tocopherols and other vitamins [2, 15, 23-25] and flavonoids [20, 26]. Niki and Noguchi [27] reported that $\alpha$-tocopherol acts as an antioxidant not only by itself but also in collaboration with other antioxidants. The addition of 100,200 or $300 \mathrm{ppm} \delta$-tocopherol in seed oil samples, and hence the significant increase of the 
coantioxidant ( $\delta$-tocopherol) concentration, reduced the depletion of all tocopherols (Table 2) after irradiation with 1, 2 and 3KGy. $\alpha$-Tocopherol depletion was reduced by $15.4 \%$ and $18.5 \%$ (for soybean and sunflower oil, respectively), $\gamma$-tocopherol by $19.2 \%$ (for soybean oil) and $\delta$-tocopherol by $5.2 \%$ and $12.8 \%$ (for soybean and sunflower oil, respectively). These results can explain why the drop of induction period of all oils was reduced when $\delta$-tocopherol was added. The results are in agreement with those of Zhu et al. [20] who demonstrated that LDL oxidation did not occur substantially until atocopherol was depleted.

In conclusion, the present study demonstrated that the effect of irradiation on the oxidative condition of oils was minimized when $\delta$-tocopherol was added. At the same time the tocopherol content was reduced considerably. The addition of $\delta$-tocopherol can reduce, in most cases, the loss of $\alpha$ - and $\gamma$ - tocopherols and hence retain the nutritional value of lipid foods. From a nutritional perspective, the protection of $\alpha$-tocopherol, which possesses over $80 \%$ of biological activity of all tocopherols, is important since this vitamin is an integral component of biological membranes, where it acts as a highly effective chain-breaking antioxidant and inhibits phospholipids and cholesterol oxidation [14]. Further investigation on the effect of irradiation on tocopherol content and induction period of lipid foods using higher doses and $\delta$-tocopherol concentrations should be carried out in combination to the mechanism of action of various tocopherols.

\section{Experimental Section}

Three different vegetable oils were used, namely olive oil, sunflower oil and soybean oil (all purchased from Elais s.a, Athens, Greece). In sunflower and soybean oil samples 0, 100, 200 or $300 \mathrm{ppm}$ of $\delta$-tocopherol (Sigma Chemicals Company Ltd., St. Louis, USA) were added (Table 2) before irradiation takes place. Each determination was also carried out on a sample of seed oil (Control) (with or without addition of $\delta$-tocopherol) not subjected to irradiation.

\subsection{Irradiation}

Oils were placed in sealed screw capped glass vials $(5 \mathrm{~cm}$ in length, i.d. $2 \mathrm{~cm})$ and then irradiated with doses of 1, 2, and $3 \mathrm{kGy}$, at room temperature, using as gamma source ${ }^{60} \mathrm{Co}$ (Theratron 1000 for radiotherapy applications, MDS Nordion, Ottawa, Canada). The irradiation was carried out at Department of Oncology and Radiotherapy of I.K.A. in G. Genimatas Oncology Hospital (Athens, Greece). The irradiated samples and unirradiated controls were stored, with nitrogen induced, at $-20{ }^{\circ} \mathrm{C}$ for approximately 1 day before induction period and tocopherol content determination.

\subsection{Rancimat method}

The determination was carried out using the method described by Lalas and Dourtoglou [28]. Two and a half grams of oil were accurately weighed into the reaction vessel of the Rancimat 679 (Metrhom LTD, Herisau, Switzerland). The conditions were set at $90{ }^{\circ} \mathrm{C}$ and 15 liter/h. 
Table 1. Induction period $\left(90{ }^{\circ} \mathrm{C}\right.$ and $\left.15 \mathrm{~L} / \mathrm{h}\right)$ of vegetable oils with and without irradiation.

\begin{tabular}{|c|c|c|c|c|c|}
\hline Oil & Added $\delta$-tocopherol (ppm) & Control & Irradiated 1KGy & Irradiated $2 \mathrm{KGy}$ & Irradiated 3KGy \\
\hline \multirow{2}{*}{ Olive } & \multirow[t]{2}{*}{0} & $149.7^{\mathrm{a}^{*}}$ & $143.2^{\mathrm{b}}$ & $139.8^{c}$ & $135.3^{\mathrm{d}}$ \\
\hline & & $(1.5)$ & $(0.3)$ & $(1.9)$ & $(0.4)$ \\
\hline \multirow{8}{*}{ Soybean } & \multirow[t]{2}{*}{0} & $31.0^{\mathrm{a}}{ }_{\mathrm{A}}$ & $29.9^{\mathrm{b}}{ }_{\mathrm{A}}$ & $28.9^{\mathrm{c}}{ }_{\mathrm{A}}$ & $20.4{ }_{\mathrm{A}}^{\mathrm{d}}$ \\
\hline & & $(0.2)$ & $(0.3)$ & $(0.2)$ & $(0.2)$ \\
\hline & \multirow[t]{2}{*}{100} & $31.7^{\mathrm{a}}{ }_{\mathrm{B}}$ & $30.9^{\mathrm{b}}{ }_{\mathrm{B}}$ & $30.0^{\mathrm{c}}{ }_{\mathrm{B}}$ & $23.2^{\mathrm{d}}{ }_{\mathrm{B}}$ \\
\hline & & $(0.6)$ & $(0.3)$ & $(0.4)$ & $(0.3)$ \\
\hline & \multirow[t]{2}{*}{200} & $32.9^{\mathrm{a}}{ }_{\mathrm{C}}$ & $32.4^{\mathrm{b}}{ }_{\mathrm{C}}$ & $31.7^{\mathrm{c}} \mathrm{C}$ & $25.1^{\mathrm{d}} \mathrm{C}$ \\
\hline & & $(0.2)$ & $(0.2)$ & $(0.2)$ & $(0.2)$ \\
\hline & \multirow[t]{2}{*}{300} & $35.0^{\mathrm{a}} \mathrm{D}$ & $33.2^{\mathrm{b}}{ }_{\mathrm{D}}$ & $32.8^{\mathrm{c}} \mathrm{D}$ & $27.5^{\mathrm{d}} \mathrm{D}$ \\
\hline & & $(0.2)$ & $(0.2)$ & $(0.3)$ & $(0.4)$ \\
\hline \multirow{8}{*}{ Sunflower } & \multirow[t]{2}{*}{0} & $23.3^{\mathrm{a}} \mathrm{A}$ & $22.0^{\mathrm{b}}{ }_{\mathrm{A}}$ & $21.3^{\mathrm{c}} \mathrm{A}$ & $17.3^{\mathrm{d}}{ }_{\mathrm{A}}$ \\
\hline & & $(0.6)$ & $(0.2)$ & $(0.2)$ & $(0.3)$ \\
\hline & \multirow[t]{2}{*}{100} & $25.0^{\mathrm{a}}{ }_{\mathrm{B}}$ & $22.9^{\mathrm{b}}{ }_{\mathrm{B}}$ & $21.9^{\mathrm{c}}{ }_{\mathrm{B}}$ & $19.0^{\mathrm{d}}{ }_{\mathrm{B}}$ \\
\hline & & $(0.5)$ & $(0.2)$ & $(0.4)$ & $(0.3)$ \\
\hline & \multirow[t]{2}{*}{200} & $26.3^{\mathrm{a}} \mathrm{C}$ & $24.0^{\mathrm{b}}{ }_{\mathrm{C}}$ & $23.3^{\mathrm{c}} \mathrm{C}$ & $20.2{ }^{\mathrm{d}} \mathrm{C}$ \\
\hline & & $(0.6)$ & $(0.2)$ & $(0.2)$ & $(0.3)$ \\
\hline & \multirow[t]{2}{*}{300} & $27.2^{\mathrm{a}} \mathrm{D}$ & $25.8^{\mathrm{b}}{ }_{\mathrm{D}}$ & $24.8^{\mathrm{c}} \mathrm{D}$ & $22.3{ }^{\mathrm{d}} \mathrm{D}$ \\
\hline & & $(0.3)$ & $(0.2)$ & $(0.3)$ & $(0.4)$ \\
\hline
\end{tabular}

*Values are mean and standard deviation (in parenthesis) of triplicate determinations. Means of each individual tocopherol within each row with different superscripts are significantly $(\mathrm{P}<0.05)$ different. Means of each individual tocopherol for each oil within each column with different subscripts are significantly $(\mathrm{P}<0.05)$ different. 
Table 2. Tocopherol content (ppm) of vegetable oils before and after irradiation.

\begin{tabular}{|c|c|c|c|c|c|c|c|c|c|c|c|c|c|}
\hline \multirow[b]{2}{*}{ Oil } & \multirow{2}{*}{$\begin{array}{l}\text { Added } \\
\delta \text {-tocopherol } \\
(\mathrm{ppm}) \\
\end{array}$} & \multicolumn{4}{|c|}{$\alpha$-tocopherol } & \multicolumn{4}{|c|}{$\gamma$-tocopherol } & \multicolumn{4}{|c|}{$\delta$-tocopherol } \\
\hline & & Control & 1KGy & 2KGy & 3KGy & Control & 1KGy & 2KGy & 3KGy & Control & 1KGy & 2KGy & 3KGy \\
\hline Olive & 0 & $\begin{array}{l}151.7^{\mathrm{a}} \\
(11.5)\end{array}$ & $\begin{array}{l}100.2^{\mathrm{b}} \\
(4.8)\end{array}$ & $\begin{array}{l}82.1^{\mathrm{c}} \\
(0.5)\end{array}$ & $\begin{array}{l}48.1^{\mathrm{d}} \\
(0.4)\end{array}$ & $\begin{array}{l}9.9^{\mathrm{a}} \\
(1.2) \\
\end{array}$ & $\begin{array}{l}3.1^{\mathrm{b}} \\
(0.1)\end{array}$ & $\begin{array}{l}0.0^{\mathrm{c}} \\
(0.0)\end{array}$ & $\begin{array}{l}0.0^{\mathrm{c}} \\
(0.0) \\
\end{array}$ & $\begin{array}{l}4.6^{\mathrm{a}} \\
(0.4) \\
\end{array}$ & $\begin{array}{l}1.0^{\mathrm{b}} \\
(0.1)\end{array}$ & $\begin{array}{l}0.0^{c} \\
(0.0) \\
\end{array}$ & $\begin{array}{l}0.0^{c} \\
(0.0)\end{array}$ \\
\hline \multirow{4}{*}{$\begin{array}{l}\tilde{\Xi} \\
\text { Dेँ } \\
\text { हैं }\end{array}$} & 0 & $\begin{array}{l}127.0{ }^{\mathrm{a}} \mathrm{A} \\
(2.0)\end{array}$ & $\begin{array}{l}71.7^{\mathrm{b}} \\
(1.5) \\
\end{array}$ & $\begin{array}{l}32.3^{\mathrm{c}}{ }_{\mathrm{A}} \\
(1.9)\end{array}$ & $\begin{array}{l}9.4{ }^{\mathrm{d}}{ }_{\mathrm{A}} \\
(0.2)\end{array}$ & $\begin{array}{l}512.3{ }^{\mathrm{a}}{ }_{\mathrm{A}} \\
(18.2)\end{array}$ & $\begin{array}{l}237.6^{\mathrm{b}}{ }_{\mathrm{A}} \\
(2.2)\end{array}$ & $\begin{array}{l}108.5^{\mathrm{c}}{ }_{\mathrm{A}} \\
(1.5)\end{array}$ & $\begin{array}{l}39.7^{\mathrm{d}}{ }_{\mathrm{A}} \\
(1.5)\end{array}$ & $\begin{array}{l}293.0^{\mathrm{a}}{ }_{\mathrm{A}} \\
(10.8)\end{array}$ & $\begin{array}{l}117.2^{\mathrm{b}}{ }_{\mathrm{A}} \\
(1.7)\end{array}$ & $\begin{array}{l}57.3{ }^{\mathrm{c}} \mathrm{A} \\
(6.5)\end{array}$ & $\begin{array}{l}20.2^{\mathrm{d}}{ }_{\mathrm{A}} \\
(0.6)\end{array}$ \\
\hline & 100 & $\begin{array}{l}129.0^{\mathrm{a}}{ }_{\mathrm{A}} \\
(1.0)\end{array}$ & $\begin{array}{l}82.3^{\mathrm{b}}{ }_{\mathrm{B}} \\
(0.4)\end{array}$ & $\begin{array}{l}41.2^{\mathrm{c}}{ }_{\mathrm{B}} \\
(0.7)\end{array}$ & $\begin{array}{l}13.7^{\mathrm{d}}{ }_{\mathrm{B}} \\
(0.4)\end{array}$ & $\begin{array}{l}516.3^{\mathrm{a}}{ }_{\mathrm{A}} \\
(1.2)\end{array}$ & $\begin{array}{l}289.2^{\mathrm{b}}{ }_{\mathrm{B}} \\
(2.5)\end{array}$ & $\begin{array}{l}130.0^{\mathrm{c}}{ }_{\mathrm{B}} \\
(1.7)\end{array}$ & $\begin{array}{l}68.4^{\mathrm{d}}{ }_{\mathrm{B}} \\
(1.2)\end{array}$ & $\begin{array}{l}390.7^{\mathrm{a}}{ }_{\mathrm{B}} \\
(2.1)\end{array}$ & $\begin{array}{l}156.3^{\mathrm{b}}{ }_{\mathrm{B}} \\
(1.5)\end{array}$ & $\begin{array}{l}90.7^{\mathrm{c}}{ }_{\mathrm{B}} \\
(1.5)\end{array}$ & $\begin{array}{l}39.2^{\mathrm{d}}{ }_{\mathrm{B}} \\
(1.1)\end{array}$ \\
\hline & 200 & $\begin{array}{l}128.3^{\mathrm{a}}{ }_{\mathrm{A}} \\
(1.5) \\
\end{array}$ & $\begin{array}{l}98.9^{\mathrm{b}}{ }_{\mathrm{C}} \\
(0.4) \\
\end{array}$ & $\begin{array}{l}53.6^{\mathrm{c}}{ }_{\mathrm{C}} \\
(2.4)\end{array}$ & $\begin{array}{l}20.1^{\mathrm{d}}{ }_{\mathrm{C}} \\
(0.3)\end{array}$ & $\begin{array}{l}511.7^{\mathrm{a}}{ }_{\mathrm{A}} \\
(3.8)\end{array}$ & $\begin{array}{l}331.3^{\mathrm{b}}{ }_{\mathrm{C}} \\
(1.1)\end{array}$ & $\begin{array}{l}164.7^{\mathrm{c}} \mathrm{C} \\
(1.5)\end{array}$ & $\begin{array}{l}101.2^{\mathrm{d}} \mathrm{C} \\
(1.1)\end{array}$ & $\begin{array}{l}470.0^{\mathrm{a}}{ }_{C} \\
(18.0)\end{array}$ & $\begin{array}{l}197.4^{\mathrm{b}} \mathrm{C} \\
(2.1)\end{array}$ & $\begin{array}{l}117.3^{\mathrm{c}}{ }_{\mathrm{C}} \\
(7.5)\end{array}$ & $\begin{array}{l}42.3^{\mathrm{d}}{ }_{\mathrm{C}} \\
(1.1)\end{array}$ \\
\hline & 300 & $\begin{array}{l}130.7^{\mathrm{a}}{ }_{\mathrm{A}} \\
(2.1)\end{array}$ & $\begin{array}{l}102.7^{\mathrm{b}}{ }_{\mathrm{D}} \\
(0.8)\end{array}$ & $\begin{array}{l}67.0^{\mathrm{c}}{ }_{\mathrm{D}} \\
(1.0)\end{array}$ & $\begin{array}{l}29.8{ }_{D}^{\mathrm{d}} \\
(1.0)\end{array}$ & $\begin{array}{l}511.0^{\mathrm{a}}{ }_{\mathrm{A}} \\
(7.0)\end{array}$ & $\begin{array}{l}399.7^{\mathrm{b}}{ }_{\mathrm{D}} \\
(1.5)\end{array}$ & $\begin{array}{l}194.3^{\mathrm{c}}{ }_{\mathrm{D}} \\
(3.8)\end{array}$ & $\begin{array}{l}137.6{ }_{D}^{\mathrm{d}} \\
(1.1)\end{array}$ & $\begin{array}{l}601.3^{\mathrm{a}}{ }_{\mathrm{D}} \\
(1.1)\end{array}$ & $\begin{array}{l}216.2^{\mathrm{b}}{ }_{\mathrm{D}} \\
(1.1)\end{array}$ & $\begin{array}{l}202.3^{\mathrm{c}}{ }_{\mathrm{D}} \\
(2.5)\end{array}$ & $\begin{array}{l}72.3^{\mathrm{d}}{ }^{2} \\
(0.6)\end{array}$ \\
\hline \multirow{4}{*}{ 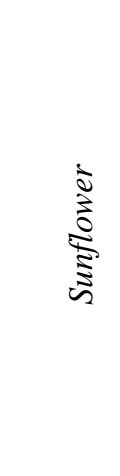 } & 0 & $\begin{array}{l}530.3^{\mathrm{a}}{ }_{\mathrm{A}} \\
(8.1)\end{array}$ & $\begin{array}{l}287.3^{\mathrm{b}}{ }_{\mathrm{A}} \\
(2.0)\end{array}$ & $\begin{array}{l}193.5^{\mathrm{c}} \mathrm{A} \\
(5.6)\end{array}$ & $\begin{array}{l}62.1_{\mathrm{A}}^{\mathrm{d}} \\
(0.9)\end{array}$ & $\begin{array}{l}12.0^{\mathrm{a}}{ }_{\mathrm{A}} \\
(0.1)\end{array}$ & $\begin{array}{l}3.6^{\mathrm{b}}{ }_{\mathrm{A}} \\
(0.3) \\
\end{array}$ & $\begin{array}{l}0.9^{\mathrm{c}}{ }_{\mathrm{A}} \\
(0.2)\end{array}$ & $\begin{array}{l}0.0^{\mathrm{d}}{ }_{\mathrm{A}} \\
(0.0) \\
\end{array}$ & $\begin{array}{l}8.8^{\mathrm{a}}{ }_{\mathrm{A}} \\
(0.7) \\
\end{array}$ & $\begin{array}{l}2.1^{\mathrm{b}}{ }_{\mathrm{A}} \\
(0.2)\end{array}$ & $\begin{array}{l}0.0^{\mathrm{c}}{ }_{\mathrm{A}} \\
(0.0)\end{array}$ & $\begin{array}{l}0.0^{\mathrm{d}}{ }_{\mathrm{A}} \\
(0.0) \\
\end{array}$ \\
\hline & 100 & $\begin{array}{l}527.7^{\mathrm{a}}{ }_{\mathrm{A}} \\
(3.2)\end{array}$ & $\begin{array}{l}340.1^{\mathrm{b}}{ }_{\mathrm{B}} \\
(4.3)\end{array}$ & $\begin{array}{l}221.0^{\mathrm{c}}{ }_{\mathrm{B}} \\
(3.0)\end{array}$ & $\begin{array}{l}95.2^{\mathrm{d}}{ }_{\mathrm{B}} \\
(0.7)\end{array}$ & $\begin{array}{l}11.7^{\mathrm{a}}{ }_{\mathrm{A}} \\
(0.3)\end{array}$ & $\begin{array}{l}5.1^{\mathrm{b}}{ }_{\mathrm{B}} \\
(0.4)\end{array}$ & $\begin{array}{l}1.2^{\mathrm{c}} \mathrm{B} \\
(0.1)\end{array}$ & $\begin{array}{c}0.0^{\mathrm{d}}{ }_{\mathrm{A}} \\
(0.0) \\
\end{array}$ & $\begin{array}{l}106.0^{\mathrm{a}}{ }_{\mathrm{B}} \\
(1.7)\end{array}$ & $\begin{array}{l}41.5^{\mathrm{b}}{ }_{\mathrm{B}} \\
(1.3)\end{array}$ & $\begin{array}{l}20.7^{\mathrm{c}}{ }_{\mathrm{B}} \\
(0.6)\end{array}$ & $\begin{array}{l}8.5^{\mathrm{d}}{ }_{\mathrm{B}} \\
(0.5)\end{array}$ \\
\hline & 200 & $\begin{array}{l}534.0^{\mathrm{a}}{ }_{\mathrm{A}} \\
(7.8)\end{array}$ & $\begin{array}{l}399.2^{\mathrm{b}}{ }_{\mathrm{C}} \\
(3.7)\end{array}$ & $\begin{array}{l}263.0^{\mathrm{c}} \mathrm{C} \\
(6.1)\end{array}$ & $\begin{array}{l}137.1^{\mathrm{d}}{ }_{C} \\
(1.2)\end{array}$ & $\begin{array}{l}11.9^{\mathrm{a}}{ }_{\mathrm{A}} \\
(0.2)\end{array}$ & $\begin{array}{l}7.4^{\mathrm{b}}{ }_{\mathrm{C}} \\
(0.4)\end{array}$ & $\begin{array}{l}1.5^{\mathrm{c}} \mathrm{C} \\
(0.1)\end{array}$ & $\begin{array}{c}0.0^{\mathrm{d}}{ }_{\mathrm{A}} \\
(0.0) \\
\end{array}$ & $\begin{array}{l}206.0^{\mathrm{a}} \mathrm{C} \\
(5.3)\end{array}$ & $\begin{array}{l}76.2^{\mathrm{b}}{ }_{\mathrm{C}} \\
(1.1)\end{array}$ & $\begin{array}{l}43.7^{\mathrm{c}}{ }_{\mathrm{C}} \\
(3.5)\end{array}$ & $\begin{array}{l}24.4^{\mathrm{d}}{ }_{\mathrm{C}} \\
(1.9)\end{array}$ \\
\hline & 300 & $\begin{array}{l}537.3^{\mathrm{a}} \mathrm{A} \\
(2.5)\end{array}$ & $\begin{array}{l}448.8^{\mathrm{b}}{ }_{\mathrm{D}} \\
(3.4)\end{array}$ & $\begin{array}{l}299.7^{c} \mathrm{D} \\
(0.7)\end{array}$ & $\begin{array}{l}162.4{ }^{\mathrm{d}} \mathrm{D} \\
(1.2)\end{array}$ & $\begin{array}{l}12.0^{\mathrm{a}}{ }_{\mathrm{A}} \\
(0.2)\end{array}$ & $\begin{array}{l}9.3^{\mathrm{b}}{ }_{\mathrm{D}} \\
(0.3)\end{array}$ & $\begin{array}{l}1.7_{\mathrm{D}}^{\mathrm{c}} \\
(0.1)\end{array}$ & $\begin{array}{l}0.0^{\mathrm{d}}{ }_{\mathrm{A}} \\
(0.0)\end{array}$ & $\begin{array}{l}304.3^{\mathrm{a}} \mathrm{D} \\
(4.9)\end{array}$ & $\begin{array}{l}116.0^{\mathrm{b}} \mathrm{D} \\
(2.0)\end{array}$ & $\begin{array}{l}63.7^{\mathrm{c}} \mathrm{D} \\
(3.5)\end{array}$ & $\begin{array}{l}39.1{ }^{\mathrm{d}} \mathrm{D} \\
(1.9)\end{array}$ \\
\hline
\end{tabular}

Values are mean and standard deviation (in parenthesis) of triplicate determinations. Means of each individual tocopherol within each row with different superscripts are significantly $(\mathrm{P}<0.05)$ different. Means of each individual tocopherol for each oil within each column with different subscripts are significantly $(\mathrm{P}<0.05)$ different. 


\subsection{Tocopherols}

The determination was carried out using the method described by Lalas and Tsaknis [29]. An HPLC pump, Waters 600E (Millipore Corporation, Waters Chromatography Division, Massachusetts, USA), equipped with a Waters $\mu$-Porasil column $(125 \AA$, $10 \mu \mathrm{m}, 3.9 \times 300 \mathrm{~mm})$ and a Waters 486 Tunable Absorbance Detector was used.

\subsection{Statistical analysis}

Results are displayed as means of triplicate determinations and standard deviation (in parenthesis). Statistical significance of the differences between mean values was assessed by ANOVA test.

\section{Acknowledgements}

The study has been co-funded by $75 \%$ from European Union and $25 \%$ from the Greek Government under the framework of the Education and Initial Vocational Training Program - EPEAEK I Archimedes.

\section{References and Notes}

1. Rodis, P. Methods of food preservation; Athanasios Stamoulis Editions: Athens, Greece, 1995; pp 354-367.

2. Niki, E.; Saito, T.; Kawakami, A.; Kamiya, Y. Inhibition of oxidation of methyl linoleate in solution by vitamin E and vitamin C. J. Biol. Chem. 1984, 259, 4177-4182.

3. Glidewell, S.M.; Deighton, N.; Goodman, B.A.; Hillman, J.R. Detection of irradiated food: A review. J. Sci. Food Agric. 1993, 61, 281-300.

4. Kilcast, D. Effect of irradiation on vitamins. Food Chem. 1994, 49, 157-164.

5. Simic, M.G. In Preservation of food by ionizing radiation; Josephson, E.S.; Peterson, M.S., Eds.; CRC Press Inc.: Florida. 1983; Vol. 2, p 1-73.

6. Stevenson, M.H. Nutritional and other implications of irradiating meat. Proc. Nutr. Sot. 1994, 53, 317-325.

7. Galvin, K.; Morissey, P.A.; Buckley, D.J. Effect of dietary $\alpha$-tocopherol supplementation and gamma-irradiation on $\alpha$-tocopherol retention and lipid oxidation in cooked minced chicken. Food Chem. 1998, 62, 185-190.

8. Diehl, J.F. In Preservation of food by ionizing radiation; Josephson, E.S.; Peterson, M.S., Eds.; CRC Press Inc.: Florida. 1983; Vol. 2, p 279-357.

9. Heath, J.L.; Owens, S.L.; Tesch, S. Effect of high-energy electron irradiation of chicken meat on thiobarbituric acid values, shear values, odour and cooked yield. Poultry Sci. 1990, 69, 313-319.

10. Hwang, K.T.; Maerker, G. Quantitation of cholesterol oxidation products in unirradiated and irradiated meats. J. Am. Oil Chem. Soc. 1993, 70, 371-375.

11. Lakritz, L.; Thayer, D.W. Effect of ionizing radiation on unesterified tocopherols in fresh chicken breast muscle. Meat Sci. 1992, 32, 257-265. 
12. Lakritz, L.; Thayer, D.W. Effect of gamma radiation of total tocopherols in fresh chicken breasts muscle. Meat Sci. 1994, 37, 439-448.

13. Lakritz, L.; Fox Jr, J.B.; Hampson, J.; Richardson, R.; Kohout, K.; Thayer, D.W. Effect of gamma radiation on levels of a-tocopherol in red meats and turkey. Meat Sci. 1995, 41, 261-271.

14. Buckley, D.J.; Morrissey, P.A.; Gray, J.I. Influence of dietary vitamin E on the oxidative stability and quality of pig meat. J. Anim. Sci. 1995, 73, 3122-3150.

15. Fuster, M.D.; Lampi, A.M.; Hopia, A.; Kamal-Eldin, A. Effects of $\alpha$ - and $\gamma$-tocopherols on the autoxidation of purified sunflower triacylglycerols. Lipids 1998, 33, 715-722.

16. Bourgeois, F.; Czornomaz, A.M. Utilisation du palmitate d' ascorbyle de l' $\alpha$-tocopherol et des phospholipides pour stabiliser le saindoux. Rev. Fran. Corps Gras. 1982, 29, 111-116.

17. Von Pongracz, G.; Hoffmann-La Roche, F.; Basel, A.G. $\gamma$-Tocopherol als natürliches antioxidans. Fette Seif. Anstrich. 1984, 12, 455-460.

18. Kiritsakis, A. The Olive Oil; Kafatos, A., Ed; Agricultural Co-operative Editions: Thessaloniki, Greece, 1988; p 52, 61-64 and 234.

19. Kiritsakis, A.; Min, D.B. In Flavour Chemistry of Lipid Foods; Min D.B., Ed.; The American Oil Chemists' Society: Illinois, 1989; p 196-221.

20. Zhu, Q.Y.; Huang, Y.; Chen, Z.Y. Interaction between flavonoids and a-tocopherol in human low density lipoprotein. J. Nutr. Biochem. 2000, 11, 14-21.

21. Baldioli, M.; Servili, M.; Perretti, G.; Montedoro, G.F. Antioxidant activity of tocopherols and phenolic compounds of virgin olive oil. J. Am. Oil Chem. Soc. 1996, 73, 1589-1593.

22. Schuler, P. In Food antioxidants; Hudson, B.J.F. Ed.; Elsevier Applied Science: London, 1990; p 99-170.

23. Barclay, L.C.R.; Locke, G.J.; MacNeil, J.M. Autoxidation in micelles. Synergism of vitamin C with lipid-soluble vitamin E and water-soluble Trolox. Can. J. Chem. 1985, 63, 366-374.

24. Doba, T.; Burton, G.W.; Ingold, K.U. Antioxidant and co-antioxidant activity of vitamin C, either alone or in the presence of vitamin $\mathrm{E}$ or a water-soluble vitamin $\mathrm{E}$ analogue, upon the peroxidation of aqueous multilamellar phospholipid liposomes. Biochim. Biophys. Acta. 1985, 835, 298-303.

25. Niki, E.; Kawakami, A.; Yamamoto, Y.; Kamiya, Y. Oxidation of lipids. VIII. Synergistic inhibition of oxidation of phosphatidylcholine liposome in aqueous dispersion by vitamin $\mathrm{E}$ and vitamin C. Bull. Chem. Soc. Jpn. 1985, 58, 1971-1975.

26. Pedrielli, P.; Skibsted, L. H. Antioxidant synergy and regeneration effect of quercetin, (-)epicatehin, and (+)-catechin on $\alpha$-tocopherol in homogenous solutions of peroxidating methyl linoleate. J. Agric. Food Chem. 2002, 50, 7138-7144.

27. Niki, E.; Noguchi, N. Dynamics of antioxidant action of vitamin E. Acc. Chem. Res. 2004, 37, 4551.

28. Lalas, S.; Dourtoglou, V. Use of rosemary extract in preventing oxidation during deep fat frying of potato chips. J. Am. Oil Chem. Soc. 2003, 80, 579-583.

29. Lalas, S.; Tsaknis, J. Characterisation of Moringa oleifera, variety PKM1 seed oil. J. Food Comp. Anal. 2002, 15, 65-77.

(C) 2007 by MDPI (http://www.mdpi.org). Reproduction is permitted for noncommercial purposes. 